\title{
KOEKSISTENSI DAMAI DALAM MASYARAKAT MUSLIM MODERNIS
}

\author{
Hendar Riyadi \\ Dosen Sekolah Tinggi Agama Islam (STAI) Muhammadiyah Bandung \\ J1. K.H Ahmad Dahlan (Banteng) Dalam No. 6 Bandung 40163, Indonesia \\ E-mail: hendarriyadi@ymail.com
}

\begin{abstract}
This study argues that puritan Islam is not always being a threat to pluralism. This is evidenced by modern Muslims (Muhammadiyah) in Arjasari of Bandung District, whose views and attitudes tend towards a peaceful coexistence. They have positive view of diversity of religions; they empasize charity dialogue (not violance) in competing with Christian missionary activities; and their social behavior and acts show tolerance and peaceful coexistence with nonMuslim family. These experiences are correcting the claim of some scholars that puritan Islam can hardly accept religious diversity and even viewed as threat to pluralism. Using qualitative methods, this study concludes that the Muhammadiyah Muslim community of Arjasari shows a positive view of pluralism and peaceful coexistence attitude towards non-Muslims, and, hence, that puritan Islam is not a threat to pluralism.
\end{abstract}

Keywords:

Muslim modernist; Muhammadiyah; puritan; pluralism; peaceful coexistence.

\begin{abstract}
Abstrak
Studi ini berargumen bahwa Islam puritan tidak selalu menjadi ancaman terhadap pluralisme. Ini dibuktikan oleh kaum Muslim modern (Muhammadiyah) di Arjasari daerah Bandung, yang pandangan-pandangan dan sikapsikapnya cenderung ke arah koeksistensi damai. Mereka memiliki pandangan positif tentang keragaman agamaagma; mereka menekankan dialog amal (bukan kekerasan) dalam menyaingi aktivitas misionaris Kristen; dan tingkah laku dan tindakan-tindakan sosial mereka menunjukkan toleransi dan koeksistensi damai dengan keluarga non-Muslim. Semua ini mengoreksi klaim sebagian sarjana bahwa Islam puritan hampir tidak dapat menerima keragaman agama-agama dan bahkan dipandang sebagai ancaman terhadap pluralisme. Dengan menggunakan metode kualitatif, studi ini berkesimpulan bahwa komunitas Muslim Arjasari menunjukkan pandangan yang positif tentang pluralisme dan koeksistensi damai terhadap non-Muslim, dan dari sini, bahwa Islam puritan bukanlah ancaman terhadap pluralisme.
\end{abstract}

Kata Kunci:

Muslim modernis; Muhammadiyah; puritan; pluralism; koeksistensi perdamaian.

\section{DOI: http://dx.doi.org/10.15575/jw.v39i1.575}

Received: October 2015 ; Accepted: December 2015 ; Published: February 2016

\section{A. PENDAHULUAN}

Radikalisme atau kekerasan dalam agama dan atas nama agama masih cukup mengkhawatirkan. Di Indonesia, menurut beberapa laporan, hal ini masih menunjukkan tren yang meningkat. Jawa Barat adalah salah satu daerah yang cukup tinggi dan rawan dalam tindak kekerasan berlatar agama ini. ${ }^{1}$ Di antara

\footnotetext{
${ }^{1}$ CRCS, Laporan Tahunan Kehidupan Beragama 2010 (Yogyakarta: Sekolah Pascasarjana, Universitas Gadjah Mada, 2010), 37. Data tahun 2010 seperti yang dilansir oleh Aliansi Kebangsaan untuk Kerukunan Beragama, kekerasan berlatar belakang agama meningkat dibandingkan 2009. Jawa Barat masih merupakan daerah yang memiliki catatan kekerasan berlatar belakang agama tertinggi. Hingga September
}

isu krusial dari tindak kekerasan berlatar agama adalah berkait isu pluralisme agama, khususnya menyangkut keberadaan Ahmadiyah, penutupan rumah ibadah dan isu Kristenisasi. Mengenai isu Ahmadiyah mi-

2010 tercatat 117 kasus, lebih tinggi dibandingkan 2009 yang mencatat 114 kasus, belum termasuk kasus HKBP di Ciketing dan pembakaran masjid Ahmadiyah di Ciampea, Bogor. http://www.media indonesia.com/ citizen read/1202, diunduh pada Sabtu, 30 Juli 2011. Hingga 2012 masih terjadi sejumlah kasus kekerasan berlatar agama yang sama di Jawa Barat. Hal ini menunjukan belum adanya kemajuan yang berarti dalam penyelesaian konflik-konflik dan kekerasan yang berlatar belakang agama. Lihat, CRCS, Laporan Tahunan Kehidupan Beragama 2012 (Yogyakarta: Sekolah Pascasarjana, Universitas Gadjah Mada, 2012). 
salnya, masyarakat Muslim di Jawa Barat, seperti yang diwakili oleh sejumlah Ormas Islam (NU, Muhammadiyah, Persis, MUI, FUUI, PUI, al-Irsyad, dll.), sangat keras menolak keberadaannya, karena dianggap menyimpang dari keyakinan teologi Islam yang benar. Hampir semua Ormas Islam menolak keberadaannya. Mereka dianggap sesat dan di luar Islam. ${ }^{2}$ Bahkan, sebagian pengurus dan anggota Ormas Islam juga memperlihatkan sikap penolakannya dalam bentuk kekerasan, baik verbal (wacana penyesatan, peng-kafiran atau pengiblisan) maupun fisik (pengusiran, pengrusakan tempat ibadah dan penghilangan nyawa). ${ }^{3}$

Isu krusial lainnya adalah penutupan rumah ibadah atas alasan pendirian/ penggunaan tanpa izin serta isu Kristenisasi. Persoalan ini telah lama muncul, namun tidak pernah tuntas terselesaikan, sehingga sampai saat ini masih menyimpan benih-benih konflik potensial lainnya di antara umat beragama. Beberapa kasus seperti di GKI Taman Yasmin Bogor dan gereja HKBP Filadelfia Bekasi, terusmenerus menjadi persoalan yang seolah tidak terselesaikan.

Di antara daerah di Jawa Barat yang cukup rawan konflik berlatar-keagamaan adalah Kecamatan Arjasari, Kabupaten Bandung. Isu Ahmadiyah, sudah tidak ada lagi persoalan karena segera dapat diantisipasi. Namun isu rumah ibadah dan Kristenisasi masih menyimpan riak-riak ketegangan. Di sini, beberapa kali telah terjadi penyerangan rumah kebaktian Kristiani oleh gerakan yang mengatasnamakan AGAP (Aliansi Gerakan Anti Pemurtadan) dan GARIS (Gerakan Islam Reformis).

\footnotetext{
${ }^{2}$ Lihat antara lain pernyataan sikap Nahdhatul Ulama (NU) dalam http://www.nu.or.id/ page/id/dinamic_detil/6/12315/Taushiyah/Sikap_PBNU tentang_Ahmadiyah.html; pernyataan sikap Persatuan Islam, dalam http://persis.or.id/?mod=content\&cmd= news\&berita_id=1352 persis dan ahmadiyah; pernyataan sikap al-Irsyad al-Islamiyah, dalam http://alirsyad.net/index.php?option=com_content\&task =view\&id=119\&Itemid=1.

${ }^{3}$ KONTRAS, Laporan Hak Asasi Manusia Peristiwa Penyerangan Jama'ah Ahmadiyah Cikeusik 6 Februari 2011 (Jakarta: Komisi untuk Orang Hilang dan Tindak Kekerasan, 2011), 5-9.
}

Rumah kebaktian ini telah berdiri sejak 2004 dan masih ada hingga sekarang. Beberapa aparat pemerintah setempat menerangkannya sudah tidak lagi diguna-kan. Namun, menurut warga yang tinggal di dekatnya, rumah ini masih digunakan sekalipun tidak setiap saat atau minggu. Menariknya, rumah ibadah ini berada persis di samping masjid (mushala) yang biasa digunakan tempat shalat dan pengajian warga Muslim setempat. Ini unik, bagaimana mungkin di tengah-tengah lokasi yang berpenduduk mayoritas Muslim terdapat rumah ibadah Kristiani, terlebih posisinya berdampingan dengan mushala. Lalu pertanyaannya, adakah disana koeksistensi (hidup berdampingan) damai antara Muslim dan Kristiani.

Lebih menariknya lagi, di antara warga Muslim Arjasari itu ada yang berafiliasi dengan Ormas Islam modernis, yakni $\mathrm{Mu}-$ hammadiyah, yang dalam sejumlah studi dianggap berpandangan puritan dan sulit menerima kehadiran orang beragama lain. Mereka bahkan dianggap mengancam pluralisme. ${ }^{4}$ Belakangan, Muhammadiyah juga kerap dihubungkan bahkan disama-kan dengan gerakan Wahabi, dan dicitrakan oleh sebagian penulis dan pengamat sebagai puritan, intoleran, radikal, lebih dekat kepada nalar homogenitas, berwatak konservatif, dan bahkan fundamentalis. ${ }^{5}$ Ini tentu berlawanan dengan citra yang selama ini terbangun, bahwa Muhammadiyah adalah gerakan Islam modernis liberal dan progresif, ${ }^{6}$ yang lebih

${ }^{4}$ Lihat, Suaidi Asyari, Nalar Politik NU \& Muhammadiyah, terj. Mohamad Rapik (Yogyakarta: LKiS, 2010), 34; Nur Khalik Ridwan, Agama Borjuis, Kritis Atas Nalar Islam Murni (Yogyakarta: Ar-Ruzz, 2004), 15-185; Fatimah Husein, Muslim-Christian Relations in The New Order Indonesia, The Exclusivist and Inclusivist Muslims Perspective (Bandung: Mizan, 2005), 32-34.

${ }^{5}$ M. Dawam Rahardjo, "Dari Puritanisme Ke Fundamentalisme: Muhammadiyah Berbalik Arah," dalam Esai-Esai Pemikiran Moh. Shofan Dan Refleksi Kritis Kaum Pluralis, (ed.) Ali Usman (Jakarta: LSAF dan Ar-Ruzz Media, 2008), 232-239; Ridwan, Agama Borjuis, Kritis Atas Nalar Islam Murni, 16-21.

${ }^{6}$ Lihat Deliar Noer, Gerakan Modern Islam Di Indonesia 1900-1942 (Jakarta: LP3ES, 1980); James L. Peacock, Purifying the Faith: The Muhammadiyah 
toleran, moderat dan sangat terbuka terhadap kemajemukan. $^{7}$ Tesis-tesis ini tentu perlu kajian lebih lanjut. Benarkah Muhammadiyah sebagai gerakan Islam modernis-puritan sulit menerima keragaman dan bahkan mengancam pluralisme? Bagaimana kaum Muslim modernis (Muhammadiyah) Arjasari Kabupaten Bandung memandang pluralisme dan koeksistensi damai? Isu-isu inilah yang menjadi kajian sentral dalam tulisan ini.

\section{B. HASIL DAN PEMBAHASAN}

\section{Pluralisme Agama: Antara Eksklusif, Inklusif dan Pluralis}

Isu pluralisme agama hingga kini masih cukup kontroversial dalam masyarakat Muslim, terlebih setelah dinyatakan haram oleh fatwa Majelis Ulama Indonesia (MUI). ${ }^{8}$ Meski begitu, tidak ada konsensus mengenai definisinya. Para sarjana dan ulama berbeda pendapat. MUI, misalnya, mendefiniskan pluralisme agama sebagai paham yang mengajarkan bahwa semua agama sama, bahwa kebenaran setiap agama adalah relatif. Karenanya, setiap pemeluk agama tidak boleh mengklaim agamanya sajalah yang benar dan lainnya salah. MUI membedakan pluralisme agama dari pluralitas agama yang dipahaminya sebagai kenyataan koeksistensinya

Movement in Indonesian Islam (California: The Benyamin/Cumming Publishing Company, 1978); Alfian, Muhammadiyah, The Political Behavior of A Muslim Modernist Organization Under Dutch Colonialism (Yogyakarta: Gajah Mada University Press, 1989); W. Montgomery Watt, Islamic Fundamentalism and Modernity (London: Routledge, 1988); Charles Kurzman, Wacana Islam Liberal, Pemikiran Islam Kontemporer Tentang Isu-Isu Global, terj. Bahrul Ulum (et.al) (Jakarta: Paramadina, 2003); Fazlur Rahman, Islam Dan Modernitas Tentang Transformasi Intelektual (Bandung: Pustaka, 1985); Greag Fealy, Ijtihad Politik Ulama, Sejarah NU 19521967 (Yogyakarta: LKiS, 2003).

${ }^{7}$ Achmad Jainuri, Ideologi Kaum Reformis: Melacak Pandangan Keagamaan Muhammadiyah Periode Awal (Surabaya: Lembaga Pengkajian Agama dan Masyarakat, 2002), 112-127.

${ }^{8}$ Lihat, Majelis Ulama Indonesia, Himpunan Fatwa Majelis Ulama Indonesia, 92-97 (Jakarta: Erlangga, 2005), 92-97. berbagai pemeluk agama dalam suatu negara atau daerah tertentu.

Anis Malik Thoha, dengan merujuk istilah pluralisme dalam kamus bahasa Inggris, berkesimpulan bahwa pluralisme dapat disederhanakan sebagai koeksistensinya berbagai kelompok atau keyakinan dalam satu waktu tanpa kehilangan perbedaan dan karakteristik masing-masing. Sedangkan jika dirangkai dengan agama, Anis menyimpulkannya sebagai kondisi hidup-bersama (koeksistensi) antar agama yang berbeda-beda dalam satu komunitas tanpa melepaskan ciri spesifik atau ajarannya masing-masing. ${ }^{10}$ Pluralisme agama dalam pengertian asli (dictionary definition) ini, demikian Anis menyebutnya, berbeda dari "pluralisme agama" versi MUI, namun lebih dekat dengan versi pluralitas agamanya.

Pluralisme agama yang dipahami MUI barangkali lebih dekat dengan pluralisme agama yang dipahami John Hick, seperti dikutip Anis ${ }^{11}$ sebagai berikut:

“...pluralisme [agama] adalah gagasan bahwa agama-agama besar dunia membentuk persepsi dan konsepsi yang berbeda tentang, dan karenanya responsrespons yang berbeda terhadap, Yang Real atau Yang Maha Agung, dari cara-carahidup kultural utama manusia yang beragam; dan bahwa di dalam masingmasing cara-hidup tersebut, terjadi secara nyata transformasi eksistensi manusia dari keterpusatan-kepada-diri menuju keterpusatan- kepada- Realitas-dan itu terjadi, sejauh dapat teramati manusia, sampai pada batas yang sama."

\footnotetext{
${ }^{9}$ Majelis Ulama Indonesia, Himpunan Fatwa Majelis Ulama Indonesia, 96.

${ }^{10}$ Anis Malik Thoha, Tren Pluralisme Agama, Tinjauan Kritis (Jakarta: Perspektif, 2005), 12 dan 14.

11 "...pulralism is the view that the great world faiths embody different perceptions and conceptions of, and correspondingly different responses to, the Real or the Ultimate from within the major variant cultural ways of being human; and that within each of them the transformation of human existence from selfcentredness to Reality centredness is manifestly taking place - and taking place, so far as human observation can tell, to much the same extent". (Thoha, Tren Pluralisme Agama, Tinjauan Kritis.)
} 
Menurut Anis, Hick dalam pernyataannya ini tampaknya ingin menegaskan bahwa semua agama sejatinya adalah "manifestasimanifestasi dari realitas yang satu," dan karena itu semuanya sama dan tak ada yang lebih baik satu dari lainnya. ${ }^{12}$ Dalam pengertian inilah, pluralisme agama dianggap reduksionistik, mengebiri makna agama, ${ }^{13}$ dan bertentangan dengan pandangan Islam. ${ }^{14}$ Bahkan, pluralisme agama yang berasumsi bahwa semua agama sama-sama merupakan jalan sah menuju Tuhan yang sama atau bahwa agama merupakan persepsi relatif manusia tentang Tuhan yang mutlak, dan karenanya masing-masing pemeluk agama tidak boleh mengklaim agamanya lebih benar dari agama lainnya - sebagaimana dipahami John Hick - dianggap sebagai musuh agamaagama yang bersifat destruktif. ${ }^{15}$

Dari penjelasan di atas, tampak ada dua pengertian yang berbeda tentang pluralisme agama. Pertama, pengertian sosiologis, yang mengacu pada kehidupan bersama dan interaksi damai antar agama tanpa menghilangkan karakter dan tradisi masing-masing. Kedua, pengertian teologis, yang mengacu pada posisi tiap-tiap agama sebagai jalan yang sama-sama sah menuju Tuhan dan kebenaran yang sama. ${ }^{16}$

Dalam pengertian sosiologisnya, tidak ada masalah signifikan dengan pluralisme agama. Hampir seluruh sarjana dan ulama menerimanya sebagai suatu keniscayaan (sunnatullah). Namun, dalam pengertian teologisnya, pluralisme agama hingga kini masih merupakan wacana debatable dan kontroversial. Bagi sebagian kalangan Kristiani misalnya, hanya

\footnotetext{
${ }^{12}$ Thoha, Tren Pluralisme Agama, Tinjauan Kritis, 15. 16.

${ }^{13}$ Thoha, Tren Pluralisme Agama, Tinjauan Kritis,

14 Majelis Ulama Indonesia, Himpunan Fatwa Majelis Ulama Indonesia, 96.

${ }^{15}$ Adian Husaini, Pluralisme Musuh Agama-Agama, Pandangan Katolik, Protyestan, Hindu Dan Islam Terhadap Pluralisme Agama (Dewan Dakwah Islamiyah Indonesia, 2010), 29.

${ }^{16}$ Lihat juga, Thomas Banchoff, ed., Religious Pluralism, Globalization and World Politics (New York: Oxford University Press, 2008), 4-5.
}

Jesus Kristuslah jalan yang paling absah, unik, normatif dan hakiki bagi keselamatan "Akulah jalan, kebenaran dan hidup.Tak seorang pun dapat sampai kepada Bapa, kalau tidak melalui Aku" "17. Pandangan ini tampak dianut Gereja Katholik Roma yang selama berabadabad menempatkan diri sebagai pusat keselamatan, dengan doktrin terkenalnya extra ecclesiam nulla salus (di luar Gereja, tidak ada keselamatan). Implikasinya, Gereja ini bersikap tertutup dan berprasangka negatif terhadap agama-agama lain. Cara pandang ini juga berkembang di kalangan Gereja Protestan. Karl Barth misalnya menegaskan hanya ada satu agama yang benar, yaitu agama Kristen karena Tuhan menghendakiNya demikian. Sedangkan penganut agama lain akan binasa di neraka. ${ }^{18}$

Di kalangan Muslim, cara pandang serupa tampak dalam klaim bahwa Islam adalah agama yang paling benar di sisi Allah (Inna al-dina 'inda Allāh al-Islām). Barangsiapa yang mencari agama selain Islam, maka ia tidak akan diterima dan di akhirat termasuk orang yang merugi (wa man yabtaghi ghayra al-Isläm dinā fa lan yuqbalu minhu wa huwa fi al-ākhirati hum al-khāsirūn). Para penganut agama selainnya adalah kafir dan akan disiksa kelak di neraka. Ini misalnya dikemukakan Abdul Aziz bin Abdullah bin Baz, ulama besar yang pernah menjadi mufti besar Arab Saudi. Menurutnya, Islam pada zaman Nabi Muhammad adalah tauhid kepada Allah beserta keimanan terhadap Alquran dan mengikuti syari'atnya.Yahudi dan Nasrani, berdasarkan ijma kaum muslimin, adalah sesat dan kafir karena tidak mengimani Nabi Muhammad, sekalipun di antara mereka ada yang bertauhid kepada Allah.

Berkait dengan isu toleransi dan kesatuan agama (bahwa agama itu satu, sama), Abdullah bin Baz menyatakan bahwa tidak ada persaudaraan (ukhuwah) dan cinta kasih (mahabbah) antara kaum Muslim dan kafir. Persaudaraan hanya ada antar sesama Muslim. Tidak ada ikatan antara Islam dan Kristen.

\footnotetext{
${ }^{17}$ Yohanes 14:6

${ }^{18}$ John Hick, God and the Universe of Faiths (Philadelphia: The Westminster Press, 1982), 120-121.
} 
Sebab, Islam adalah kebenaran yang harus diikuti seluruh penduduk bumi. Sementara Kristen adalah kafir dan sesat berdasarkan nas Alquran. Kepada mereka wajib membenci dan memusuhi, serta haram mengadakan pertemanan, kerjasama dan mengambil peminpin dari mereka dalam hal apapun termasuk dalam kerjasama dalam pengkhidmatan kemanusiaan. $^{19}$

Sementara itu, kalangan lainnya mengklaim bahwa semua agama sama-sama merupakan jalan yang sah menuju Tuhan atau kebenaran yang sama. John Hick (1932-2012) adalah salah seorang teolog Kristen paling berpengaruh yang banyak disebut-sebut mengusung cara pandang ini. Dalam beberapa karyanya, ${ }^{20}$ Hick mengajukan sejumlah hipotesis dan teori mengenai pluralisme agama. Setidaknya ada tiga tesis Hick mengenai hubungan antara Kekristenan dengan agama-agama lainnya. Pertama, sadar atau tidak sadar, Kristen hidup dalam konteks dunia yang plural secara religius. Ini artinya, Kristen bukan sebagai satu-satunya agama, tetapi hanyalah salah satu dari sekian banyak agama. Kedua, keragaman agama tersebut menunjukan bahwa sekalipun berbeda dalam pengalaman, pemikiran dan spiritualitas, namun semua agama pada dasarnya sama, yakni jalan keselamatan yang berpusat pada Tuhan. Ketiga, karena semua agama sama, maka tidak mungkin menetapkan adanya superioritas moral penganut agama atas agama atau tradisi besar yang lainnya. ${ }^{21}$

Hick kemudian mengklaim perlunya revolusi Covernikan atas teologi agamaagama, khususnya Kristen, yang masih

\footnotetext{
${ }^{19}$ Abdul Aziz bin Abdullah bin Baz, Majmū' Fatāwà Wa Maqālāt Al-Mutanawwi'àt, juz. II, , t.t, 173-177.

${ }^{20} \mathrm{Di}$ antara karya-karya Hick yang cukup populer adalah An Interpretation of Religion (London (Macmillan; New Haven: Yale University Press, 1989); Problem of Religious Pluralism (London: Macmillan; NY: St Martin's, 1985); God and the Universe of Faiths (Philadelphia: The Westminster Press, 1982);The Metaphor of God Incarnate (Louisville: Westminster/John Knox, 1994); dan John Hick, A Christian Theology of Religions (Louisville: (Louisville: Westminster/John Knox, 1995).

${ }^{21}$ John Hick, God Has Many Names, Essays in The Philosophy of Religion (England: Oneworld Oxford, 1973), 7 dan 44 ..
}

memegang kuat apa yang disebutnya sebagai teologi Ptolemeus-yakni, keyakinan yang memandang agama Kristen sebagai pusat agama sementara agama-agama lainnya berputar dan berotasi disekeliling. ${ }^{22}$ Teologi ini, kata Hick, telah melahirkan superiotas Kristen atas agama-agama lainnya: tidak ada keselamatan di luar Geraja; mereka yang ingin diselamatkan harus menjadi Kristen, mengakui Yesus Kristus dan mau dibaptis atas namanya.

Bagi Hick, teologi Ptolemeus semacam ini sulit dipertahankan, terutama dalam membangun kehidupan bersama yang penuh damai dan toleransi: antar tradisi, agama dan budaya yang sangat beragam serta bertentangan. Di sinilah revolusi Copernikan diajukan Hick, melalui teori pergeseran paradigma Thomas Kuhn. Hick mengusulkan pergeseran paradigma dari teologi Ptolemaik yang menempatkan bumi (Kristen) sebagai pusat semesta (agamaagama) kepada teologi yang menempatkan matahari (Tuhan) sebagai pusat dan bumi (Kristen) sebagai planet yang setara dengan planet-planet (agama-agama) lainnya dalam lintasan evolusi dan rotasi di sekeliling-Nya. ${ }^{23}$ Dengan kata lain, pergeseran paradigma ini hendak menggeser pemusatan atas Kristen (ecclesio-sentris) menuju pemusatan kepada Tuhan (theo-sentris). Usulan pergerseran revolusioner seperti ini sebenarnya pernah direkomendasikan dalam kesimpulan Konferensi Bombay melalui paper yang disampaikan Hans Kung, dimana muncul ajuan penggeseran pemahaman agama dari ecclesiocentric kepada theo-centric. ${ }^{24}$

Klaim hipotetik Hick ini tentu berbeda kontras dengan klaim kalangan pertama di atas - sebagaimana dianut Karl Bath (Kristen) dan Abdullah bin Baz (Islam). Dalam kerangka tipologi Ninian Smart, respons Karl Bath atas pluralisme merupakan tipe eksklusif absolut (absolut exlusivism), sedangkan

\footnotetext{
${ }^{22}$ Hick, God and the Universe of Faiths, 1982, 120121.

${ }^{23}$ Hick, God and the Universe of Faiths, 1982, 130131. Lihat juga, John Hick, God Has Many Names, Essays in The Philosophy of Religion, 36.

${ }^{24}$ Hick, God and the Universe of Faiths, 1982, $131 .$.
} 
pandangan Hick tipe pluralis realistik (realism pluralism). ${ }^{25}$

Dalam Islam, cara-pandang pluralis realistik semacam ini dikembangkan Frithjof Schuon dan muridnya Sayyid Hossein Nasr dengan teori al-hikmah al-khālidah atau filsafat perenialnya. Schuon mengajukan gagasan kesatuan agama-agama pada level transenden - seperti tercermin dari salah satu judul bukunya, The Transcendent Unity of Religions-yang terjadi dalam dimensi esoterik atau batin/substansi/esensinya. Klaim agama-agama pada dimensi eksoteriknya haruslah bersifat relatif agar mereka dapat berkoeksistensi satu sama lain. Dalam dimensi esoterisnya, kata Schuon, semua agama memiliki titik temu yang sama pada Tuhan. Sementara dalam dimensi eksoteriknya, mereka merupakan manifestasi-manifestasiNya, yang meniscayakan keragaman. $^{26}$ Karenanya, bagi Schuon dan Nasr, pluralisme agama adalah kehendak Tuhan, dan karena itu mereka semua benar dan absah untuk diikuti. Dalam ungkapan Nasr, semua agama adalah jalan-jalan menuju puncak yang sama.

Berbeda dengan respons eksklusif absolut dan pluralis realistik, kalangan lain-nya merespons pluralisme agama dengan keyakian bahwa ada kebenaran dan jalan keselamtan dalam agama yang dianutannya, sembari meyakini agama-agama lainnya sebagai jalan keselamatan juga. Respons semacam ini disebut Ninian Smart sebagai tipologi inklusif hegemonistik, yakni cara pandang yang melihat ada kebenaran dalam agama lain, namun memberi prioritas bagi agamanya sendiri. Karl Rahner (1904-1984) adalah seorang teolog penting Kristen abad ke-20

\footnotetext{
${ }^{25}$ Lihat William M. Johnston, ed., Recent Reference Books in Religion: A Guide for Students, Scholars, Researchers, Buyers, \& Readers (Chicago: Fitzroy Dearborn, 1998), 116; Majelis Tarjih dan Pengembangan Pemikiran Islam PP Muhammadiyah, Tafsir Tematik Al-Quran Tentang Hubungan Sosial Antarumat Beragama (Yogyakarta: Suara Muhammadiyah, 2000), 20-23.

${ }^{26}$ Frithjof Schuon, The Transcendent Unity of Religions (India: Quest Books, 2005), xii.
}

yang mengembangkan pandangan ini. $^{27}$ Ia mengajukan konsep Anonymous Christianity (Kristen tanpa nama) untuk memperkuat posisi inklusifnya. Universalitas kasih Tuhan, menurutnya, melampaui batas-batas Kekristenan. Semua manusia tersentuh oleh karunia kasih Yesus Kristus, dan karenanya dapat ditarik ke dalam pelukan penyelamatan Allah. ${ }^{28}$

Dengan demikian, kalangan inklusif seperti Karl Rahner, mengakui keselamatan yang berlaku universal dan hadir dalam setiap agama, namun tetap mengakui keunikan Jesus Kristus. Paradigma inklusifisme ini pula yang tampaknya dikembangkan Gereja Katholik Roma setelah Konsili Vatikan II. Dalam Konsili ini dirumuskan bahwa ada keselamatan di luar Gereja. Melalui Konsili Vatikan II ini, para teolog Katolik mengajarkan bahwa kebenaran bukan monopoli Gereja. ${ }^{29}$

Dalam Islam, cara pandang inklusif ini dikembangkan sejumlah sarjana Muslim, seperti Fazlur Rahman dan Farid Esack. Keduanya sama-sama mengakui adanya keselamatan dalam setiap agama dengan tetap mempertimbangan keunikan Islam.Rahman, misalnya, merujuk dua logika kebajikan universal yang menjamin keselamatan eskatologis bagi semua komunitas agama, sebagaimana dinyatakan eksplisit dalam QS. Al-Baqarah [2]: 62, yakni iman (kepercayaan kepada Allah dan Hari Akhir) dan amal shaleh. Menurut Rahman, logika kebajikan ini merupakan sangkalan atas sikap eksklusivisme Yahudi dan Nasrani yang mengklaim sebagai satu-satunya pemilik kebenaran dan jalan keselamatan (QS. 2: 113, $119,135){ }^{30}$

\footnotetext{
${ }^{27}$ Johnston, Recent Reference Books in Religion: A Guide for Students, Scholars, Researchers, Buyers, \& Readers, 116.

${ }^{28}$ Karen Kilby, Karl Rahner, Theology and Philosophy (London and New York: Routledge: Routledge, 2004), 115-116;Declan Marmion and Mary E. Hines, ed., The Cambidge Companion to Karl Rahner (New York: Cambridge University Press, 2005), 8, 52-55.

${ }^{29}$ S.J. Aloysius Pieris, Berteologi Dalam Konteks Asia (Yogyakarta: Kanisius, 1996), 21-27.

${ }^{30}$ Fazlur Rahman, Major Theme of the Quran (Chicago: Bibliotheca Islamica, 1980), 114-115. Lihat juga, Fazlur Rahman, Tema Pokok Quran, trans. Anas
} 
Sementara itu, Esack mengemukakan setidaknya empat legitimasi penting pengakuan Alquran atas kaum beragama lain: (1) pengakuan Ahli Kitab sebagai komunitas sosio-religius penerima wahyu yang sah (QS. Al-Mukminūn [23]: 52), (2) pengakuan dua bidang sosial penting dalam hubungan antar umat beragama, yakni izin mengkonsumsi makanan dan pernikahan dengan wanita Ahli Kitab (QS. Al-Māidah [5]: 5), (3) pengakuan atas norma-norma hukum Ahli Kitab sebagai acuan penyelesaian masalah mereka (QS. AlMaidah [5]: 42, 43, 47); dan (4) pengakuan kesucian kehidupan religius penganut agama wahyu lainnya (QS. Al-Haj [22]: 40). ${ }^{31}$ Dari sini, Esack berkesimpulan bahwa Alquran lebih menempatkan inklusivitas di atas eksklusivitas, pendukung pluralisme "di atas" pendukung eksklusifisme. ${ }^{32}$

Dengan demikian, respons atas pluralisme agama tidaklah monolitik. Dari penjelasan di atas, setidaknya ada tiga cara-pandang merespons kehadiran agama-agama dan orang beragama lain, yakni eksklusivisme absolut, pluralis realistik dan inklusif hegemonistik. Hingga kini, ketiga cara pandang ini masih bersaing keras dan kerapkali melahirkan berbagai ketegangan, konflik dan kekerasan atas nama agama. Selain ketiga tipe respons ini, ada dua tipe lainnya, relativisme absolut dan pluralisme regulatif, namun penulis tidak memasukannya sebagai bagian utama studi ini.

\section{Koeksistensi Damai dan Toleransi}

Sebagaimana telah dijelaskan di atas, tujuan mendasar dari gagasan pluralisme agama adalah membangun keharmonisan, hidup

Mahyudin "Major Theme of the Quran" (Bandung: Pustaka, 1996), 237-239.

${ }^{31}$ Farid Esack, Qur'an, Liberation and Pluralism, An Islamic Perspective of Interreligious Solidarity against Oppression (England: Oxford Oneworld Publications, 1997), 3. Lihat juga, Farid Esack, Al-Quran, Liberalisme, Pluralisme, Membebaskan Yang Tertindas, trans. Watung A. Budiman "Qur'an, Liberation and Pluralism An Islamic Perspective of Interreligious Solidarity against Oppression" (Bandung: Mizan, 2000), 24-25, 160-161.

${ }^{32}$ Esack, Qur'an, Liberation and Pluralism, An Islamic Perspective of Interreligious Solidarity against Oppression, 175. berdampingan (koeksistensi) dengan penuh kedamaian dan toleransi antar keyakinan keagaman yang beragam dan terkadang saling bertentangan. Dalam hal ini, koeksistensi damai (peaceful coexistence) merupakan prinsip moral paling penting.

Dalam Cambridge Dictionary of American English, koeksistensi didefinisikan sebagai "hidup atau berada bersama secara damai pada saat atau tempat yang sama."33 Secara serupa The American Heritage Dictionary mendefinisikannya sebagai (1) "berada bersama pada saat yang sama atau ditempat yang sama"; (2) "hidup damai dengan yang lain sekalipun terdapat perbedaan terutama karena masalah kebijakan."34

Koeksistensi terjadi, kata teoritisi politik Michael Walzer, ketika sekelompok masyarakat dengan sejarah, budaya, dan identitas yang berbeda, hidup bersama secara damai. ${ }^{35}$ Menurut Mufti Besar Suriah, Sheikh Ahmad Muhammad Amin Kuftaro dalam Konferensi Hubungan Muslim-Kristen pada 1987 di Malta "koeksistensi membutuhkan dua pihak atau lebih yang ingin hidup bersama secara damai, tanpa perselisihan, pertengkaran atau konflik". Sejarahwan Bernard Lewis, ketika membahas sejarah dan kompleksitas hubungan Islam-Barat modern, menulis bahwa "koeksistensi dalam dunia kontemporer di berbagai tingkat - nasional, rasial, sosial, ideologi, dan agama - menyiratkan keinginan untuk hidup damaidan saling menghormati satu sama lain. Menurutnya, koeksistensi pragmatis, idealnya, menjadi hak kesetaraan inheren di antara kelompok masyarakat politik yang berbeda". ${ }^{36}$

Laporan Koeksistensi International (Coexistence International Report) pada 2006 secara ringkas merumuskan koeksistensi

\footnotetext{
${ }^{33}$ Aaron Tyler, Islam, The West, and Tolerance, Conceiving Coexistence (New York: Palgrave Macmillan, 2008), 4.

${ }^{34}$ Lihat, "coexistence", diakses pada 9 Desember 2013, http://www.thefreedictionary.com/coexistence.

${ }^{35}$ Michael Walzer, On Toleration, Castle Lectures in Ethics, Politics, and Economics (New Haven and London: Yale University Press, 1997), 2.

${ }^{36}$ Tyler, Islam, The West, and Tolerance, Conceiving Coexistence, 4-5.
} 
sebagai: "Sebuah konsep yang meliputi berbagai upaya di semua lapisan masyarakat untuk mengatasi tantangan yang ada, ketika kelompok (budaya dan agama) yang berbeda berusaha hidup bersama". Praktek koeksistensi bertujuan mengubah hubungan sosialpolitik, struktur dan wacana, dalam rangka meminimalisasi kekerasan dan konflik struktural. Di dalamnya, individu, kelompok dan lembaga dituntut mampu meningkatkan kapasitasnya dalam mengelola secara konstruktif konflik yang muncul tanpa kekerasan kesabaran, kerendahan hati, moderasi, dan kehati-hatian merupakan hal yang dibutuhkan. $^{37}$

Dengan demikian, sebagai prinsip moral pluralisme, toleransi dan koeksistensi tidaklah pasif. Pluralisme, kata Fathi Osman, lebih dari sekedar toleransi moral atau koeksistensi pasif-yakni, toleransi yang terkait dengan persoalan kebiasaan dan perasaan pribadi; koeksistensi yang semata-mata perkara penerimaan atas pihak lain untuk sekadar tidak terjadi konflik. Karenanya, pluralisme mestinya mensyaratkan kelembagaan dan legal yang melindungi dan menjamin kesetaraan, mengembangkan persaudaraan, serta menuntut pendekatan serius dalam upaya memahami pihak lain dan kerja sama demi kebaikan semua. $^{38}$ Dengan kata lain, pluralisme mestinya melahirkan koeksistensi produktif melalui kerja intelektual dan kemanusiaan dalam membangun peradaban dan kebajikan semesta (rahmatan li al- 'ālamīn).

\section{Muhammadiyah, Islam Modernis dan Pluralisme Agama}

Pluralitas agama di Indonesia merupakan kenyataan historis yang tak dapat disangkal siapa pun. ${ }^{39}$ Tak pelak lagi fakta ini telah

\footnotetext{
${ }^{37}$ Tyler, Islam, The West, and Tolerance, Conceiving Coexistence, 5.

${ }^{38}$ Mohammed Fathi Osman, Islam, Pluralisme Dan Toleransi Keagamaan: Pandangan Al-Quran, Kemanusiaan, Sejarah Dan Peradaban, trans. Irfan Abubakar, edisi digital (Jakarta: Democracy Project Yayasan Abad Demokrasi, t.t.), 2-3.

${ }^{39}$ M. Amin Abdullah, Studi Agama, Normativitas Atau Historisitas (Yogyakarta: Pustaka Pelajar, 1996),
} 5. melahirkan perdebatan panjang berkenaan dengan cara menyikapinya. Dari sinilah wacana baru mengenai isu pluralisme agama muncul. Berbagai kalangan merespons isu tersebut secara berbeda. Salah satunya adalah Muhammadiyah yang dikenal sebagai gerakan Islam modernis. Dari sejak awal munculnya isu tersebut, gerakan Islam modernis ini telah memberikan respons yang cukup intens, khususnya berkait dengan kehadiran Kristen.

Istilah Islam modernis umumnya dilawankan dengan Islam tradisi atau Islam rakyat. Islam tradisi merujuk pada paham keagamaan di kalangan Islam yang diasosiasikan dengan kecenderungannya pada taqlid, penolakan ijtihad, kepatuhan kepada para kiai dan syaikh yang dianggap ma'ṣum, praktek shirk dan bid'ah (seperti penghormatan terhadap keramat, memberikan sajisajian, slametan atau kendurian sebagai sedekah kepada arwah, memakai azimat, jimat atau tangkal penolak bala untuk melindungi diri). Sedangkan Islam modernis bersikap sebaliknya, yaitu menolak taklid, menerima ijtihad atau pengembangan pemikiran keagamaan, mengembangkan pemikiran rasional dan penggunaan nalar dalam memahami ajaran agama, menolak seluruh bentuk shirk dan bid'ah, serta menawarkan pemurnian ajaran Islam. Adagium yang sangat populer dari gerakan purifikasi ini adalah kembali kepada Alquran dan Sunnah (al-rujū' ilà AlQur'ān wa al-Sunnah). ${ }^{40}$

Secara umum, Muslim modernis adalah mereka yang berupaya mereformasi keimanan umat dengan memurnikannya dari unsur-unsur tradisi non-Islam, dan membuatnya relevan dengan tuntutan zaman modern melalui penyerapan metode baru di bidang teknologi,

\footnotetext{
${ }^{40}$ Lihat, Noer, Gerakan Modern Islam Di Indonesia 1900-1942, 320-324. Lihat juga, Ernest Gellner, Muslim Society (Cambridge: Cambridge University Press, 1981), 4-5; Riaz Hassan, Keragaman Iman, Studi Komparatif Masyarakat Islam, terj. Fuad Jabali, Jajang Jahroni, Udjang Tholib (PT Rajagrafindo Persada, 2006), 126-127; dan Riaz Hassan, Islam, Dari Konservatisme Sampai Fundamentalisme, terj. Dewi Haryani S. (Jakarta: CV. Rajawali, 1985), 108-109.
} 
pengorganisasian, dan pendidikan dari Barat. ${ }^{41}$ Banyak gerakan Islam modernis yang muncul antara kurun waktu 1910-an dan 1920-an. Salah satunya dan terpenting adalah Muhammadiyah, yang didirikan Ahmad Dahlan pada 18 Nopember 1912 di Kauman Yogyakarta. Satu hal penting yang membangkitkan kesadaran Muhammadiyah, dan ini terkait dengan studi kali ini, adalah kehadirannya sebagai respons terhadap penetrasi Kristen. ${ }^{42}$ Muhammadiyah, kata Alwi Shihab, tampil mengambil tanggungjawab menangkal dan menandingi kegiatan misionaris Kristen yang saat itu dirasa menakutkan atmosfer keagamaan kaum Muslim. $^{43}$ Kontak antara Muhammadiyah dan Kristen pun tak terelakan, dan di sinilah persoalan relasi Islam-Kristen (pluralisme agama) muncul dalam Muhammadiyah.

Karena konteks historis kelahirannya di atas, Muhammadiyah diasumsikan banyak penulis sulit menerima, dan bahkan menjadi ancaman terhadap pluralisme agama. Beberapa sarjana, seperti Suaidi Asyari, menyebut Muhammadiyah sebagai bagian dari kelompok gerakan Islam puritan yang cenderung mengklaim ber-Islam paling benar atau menganut Islam murni, dan karenanya merasa bertanggungjawab memurnikan keislaman muslim lainnya yang tidak sama paham teologi dan tata cara ibadahnya. Kelompok ini, lanjut Asyari-dengan merujuk Khaled Aboe El Fadl-bahkan cenderung menampilkan sikap permusuhan karena rasa superioritas atas orang lain serta menolak tradisi fiqih, seperti keberadaan madzhab hukum Islam. ${ }^{44}$

Kecenderungan lainnya dari nalar Islam murni seperti Muhammadiyah, menurut Nur Khalik Ridwan, adalah penekanannya pada

\footnotetext{
${ }^{41}$ Greag Fealy, Ijtihad Politik Ulama, Sejarah NU 1952-1967 (LKiS: Yogyakarta, 2003), 2.

${ }^{42}$ Alwi Shihab, Membendung Arus, Respons Gerakan Muhammadiyah Terhadap Penetrasi Misi Kristen Di Indonesia (Bandung: Mizan, 1998), 135-147.

${ }^{43}$ Shihab, Membendung Arus, Respons Gerakan Muhammadiyah Terhadap Penetrasi Misi Kristen Di Indonesia, 88-90, 144-146.

${ }^{44}$ Asyari, Nalar Politik NU \& Muhammadiyah, terj. Mohamad Rapik, 32-34.
}

wacana kebenaran tunggal. Ini misalnya, kata Nur Khalik, terdapat dalam nalar-nalar seperti: nalar kesempurnaan dan otentisitas Islam; nalar ketunggalan generasi Islam awal; nalar literal teks; dan nalar idealisasi Tuhan yang abstrak. Nalar Islam murni inilah yang kemudian, menurut Nur Khalik, bermetamorfosis menjadi satu-satunya jalan keselamatan, dengan ekspresinya yang menebar stigma negatif terhadap agama-agama selain Islam dan kelompok-kelompok Islam nonpemurnian. Selain itu, nalar Islam murni ini juga disinyalir telah melahirkan berbagai bentuk kekerasan wacana dan bahkan fisik, baik dalam wilayah ritual, sosial maupun politik. ${ }^{45}$ Karena itu, Muhammadiyah alih-alih mengapresiasi keragaman, malah menjadi ancaman atas pluralisme itu sendiri.

Namun demikian, beberapa sarjana lainnya, seperti Achmad Jainuri, justru melihat Muhammadiyah sebagai gerakan Islam modernis yang berwatak toleran, moderat dan sangat terbuka terhadap kemajemukan atau pluralisme. Jainuri menyebut tiga indikasi watak ini, sebagaimana tergambar dalam pandangan pendirinya, Ahmad Dahlan: Pertama, berkenaan dengan relativitas pemahaman keagamaan; kedua, toleransi; dan ketiga, penafsiran agama yang tidak absolut. ${ }^{46}$ Watak toleran, moderat dan terbuka terhadap kemajemukan itu diwujudkan oleh $\mathrm{Mu}-$ hammadiyah dalam bentuk keterbukaannya untuk melakukan dialog lintas agama, terutama berkait dengan isu-isu kebangsaan dan kemanusiaan universal. Hal ini merupakan aktualisasi dari teologi Islam berkemajuannya dalam memayungi kemajemukan untuk Indonesia yang berkemajuan.

Tesis-tesis di atas, tentu memerlukan kajian mendalam dan pengujian kritis. Sebagaimana telah disinggung, respons atas pluralisme agama tidaklah monolitik. Ninian Smart menyebut beberapa tipologi respons, antara

\footnotetext{
${ }^{45}$ Ridwan, Agama Borjuis, Kritis Atas Nalar Islam Murni, 127-142.

${ }^{46}$ Ahmad Jainuri, Ideologi Kaum Reformis: Melacak Pandangan Keagamaan Muhammadiyah Periode Awal (Surabaya: Lembaga Pengkajian Agama dan Masyarakat, 2002), 112-127.
} 
lain eksklusivisme absolut, pluralis realistik, dan inklusif hegemonistik. Sementara kerangka tipologi Kuntowijoyo menyebut dua model pluralisme, yaitu pluralisme positif atau pluralisme negatif. ${ }^{47}$ Dalam kerangka tipologi respons tersebut, dimanakah posisi $\mathrm{Mu}$ hammadiyah sebagai gerakan Islam modernis, khususnya Muhammadiyah Arjasari Kabupaten Bandung. Apakah eksklusivisme absolut, pluralisme realistik atau inklusif hegemonistik; apakah pluralisme positif atau pluralisme negatif.

\section{Koeksistensi Damai dalam Masyarakat Muslim Modernis Arjasari}

Perjumpaan Islam-Kristen, khususnya yang diwakili Muhammadiyah dan umat Kristiani, memang tidak selalu dalam suasana damai, bahkan kerap penuh ketegangan. Masingmasing sama-sama mengklaim sebagai agama keselamatan dan universal-menjadi rahmat bagi semesta alam. Keduanya sangat sulit disandingkan. Begitu juga dengan perjumpaan antara Muhammadiyah dan Kristen di Arjasari, Kabupaten Bandung, dimana ia hadir sebagai respons terhadap upaya Kristenisasi atau kegiatan pemurtadan masayarat Arjasari oleh misionaris Kristen.

Muhammadiyah Arjasari baru menampakkan kembali geliatnya pada Desember 2006an, setelah sekian lama vakum. Persoalan sumber daya manusia (kekosongan kader) tampaknya merupakan alasan utama kevakuman tersebut. Sejak itu hingga sekarang, kepengurusan Cabang Muhammadiyah Arjasari ini dipimpin Ir. H. Agus Asyari, dan telah membentuk dua Ranting, yakni Ranting Pinggirsari yang diketuai Momo Mulawarman dan Ranting Arjasari yang

\footnotetext{
${ }^{47}$ Pluralisme negatif dapat disarikan sebagai pandangan yang menganggap ada banyak agama, dan semua agama itu sama. Karenanya, orang tidak perlu memegang teguh keyakinan agamanya.Sedang pluralisme positif dimaksudkan sebagai sikap keberagamaan yang lebih mengedepankan penghormatan dan penghargaan terhadap pendapat, pilihan hidup, dan keyakinan keagamaan. Lihat, Kuntowijoyo, Muslim Tanpa Masjid, Esai-Esai Agama, Budaya Dan Politik Dalam Bingkai Strukturalisme Transendental (Bandung: Mizan, 2001), 287-289.
}

diketuai Entis Sutisna. $^{48}$ Muhammadiyah seperti dituturkan Ketua Pimpinan Ranting Muhammadiyah (PRM) Pinggirsari, Momo, menjadi garda terdepan dalam melawan upaya pemurtadan (Kristenisasi), khususnya yang terjadi di Kampung Cirungkang. Sebagai wujud kongkritnya, PRM Pinggirsari bersama PCM Arjasarinya mendirikan masjid (mushala) untuk menandingi kegiatan rumah kebaktian kaum Kristiani. Mushala tersebut berdiri persis disebelah kanan rumah ibadah Kristiani tersebut — hanya terhalang satu rumah - dengan speaker yang menghadap ke arahnya. Hingga kini mushala tersebut menjadi satu-satunya tempat ibadah dan pengajian warga Kampung Cirungkang.

Selain mendirikan mushala, Muhammadiyah juga sangat giat menyelenggarakan kegiatan-kegiatan sosial dan pemberdayaan masyarakat. Setiap tahun misalnya, $\mathrm{Mu}-$ hammadiyah selalu mengirim hewan kurban untuk kampung Cirungkang dan kampung lainnya. Mendirikan Madrasah Diniyah di Patrolsari - sekarang berpindah di Cibintinu. Mengembangkan program penggemukan kambing warga bekerjasama dengan Lembaga Amil Zakat (LAZ) Masjid Raya Mujahidin. Bersama mahasiswa ITB membuat MCK untuk warga Cirungkang. Kemudian bersama Rumah Amal Salman ITB melakukan pemberdayaan masyarakat melalui Program Kampung Bangkit. Program ini melibatkan dua kampung, yaitu kampung Cibintinu Desa Arjasari dan Kampung Cirungkang Desa Pinggirsari. Beberapa aktivitas yang dilakukan dalam penyelenggaraan program tersebut adalah: pertama, Senyum Guru, yaitu memberikan dana kepada guru ngaji; kedua, Beasiswa $\mathrm{ABC}$, memberikan beasiswa kepada anak anak; ketiga, Bakti Sosial, yaitu memberikan sumbangan kepada masyarakat; dan keempat, Pelatihan Wirausaha, yaitu usaha peternakan lele.

Seluruh kegiatan dan amal sosial Muhammadiyah di atas dipandang cukup efektif dalam membendung kegiatan

\footnotetext{
48“"Laporan Kepengurusan PCM Arjasari Masa Jabatan 2006-2011," diakses pada 16 Nopember 2013, http://pcm-arjasari.blogspot.com/.
} 
Kristenisasi. Tidak seperti gerakan-gerakan Islam lainnya, seperti AGAP (Aliansi Gerakan Anti Pemurtadan) atau GARIS (Gerakan Islam Reformis) yang lebih mengedepankan kekerasan (penyerangan langsung untuk membubarkan acara kebaktian dan melempari rumah ibadah), Muhammadiyah Arjasari justru lebih mengedepankan dialog amal atau dialog kehidupan ${ }^{49}$ dengan menggelar sejumlah program kegiatan sosial dan pemberdayaan masyarakat, seperti pengadaan sanitasi air, menggerakkan program Kampung Bangkit, dll. Walhasil, melalui kegiatankegiatan tersebut, Muhammadiyah Arjasari menjadi sangat dikenal dan diterima masyarakat, ${ }^{50}$ khususnya warga Cirungkang. Ini antara lain karena, seperti dituturkan Dadang, dalam setiap programnya (seperti program kurban) Muhammadiyah selalu melibatkan partisipasi warga, dimana mereka tidak sekedar menerima bantuan tetapi juga ikut tanggung jawab dalam pelaksanaannya.

Penekanan Muhammadiyah Arjasari pada dialog amal tidak semata atas dasar alasan sosial, tetapi juga pandangan teologis mereka sendiri mengenai pluralisme. Menurut Agus Asyari, Ketua PCM Arjasari, misalnya, menghormati cara ibadah non-Muslim merupakan hal yang penting. Menurutnya, kita tidak boleh memperolok ibadah mereka, sebab hal itu, sebagaimana diperingatkan Alquran,

\footnotetext{
${ }^{49}$ Dialog kehidupan yang dimaksudkan adalah dialog yang terjadi dalam komunitas kecil dalam menghadapi hidup keseharian bersama. Berbagai komunitas yang berbeda agama saling mengenal satu sama lain. Mereka memiliki keprihatinan bersama mengenai kebutuhan air bersih, wabah demam berdarah, perumahan yang sehat, pembejaran dan pendidikan yang sesuai, lapangan kerja, dan sebagainya.Mereka mengalami kondisi kehidupan bersama dan saling berbagi segala suka dan duka, keteguhan dan kekuatiran, pengharapan dan kecemasan. Dalam dialog kehidupan itu, anggota-anggota komunitas hidup berdampingan dengan semangat kerukunan berkomunitas, bertetangga, dan berteman. Dari pengalaman hidup bersamaitu munculah kepedulian bersama.Zainal Abidin Bagir Banawiratma, J.B. (etc.), Log Antarumat Beragama, Gagasan Dan Praktik Di Indonesia (Bandung: Mizan, 2010), 9.

${ }^{50}$ Secara lebih lengkapnya, baca "Laporan Kepengurusan PCM Arjasari Masa Jabatan 2006-2011," diakses pada 16 Nopember 2013, http://pcmarjasari.blogspot.com/.
}

hanya akan mendatangkan olok-olok yang lebih besar lagi dari mereka terhadap Tuhan kita. Namun demikian, kata Asyari, penghormatan tersebut tidak berarti pengakuan akan kebenaran mereka; tidak berarti pengakuan bahwa mereka mempunyai surga sendiri sebagaimana kita; keyakinan yang benar itu mesti satu, tidak ganda. Namun, meyakini bahwa yang beragama lain tidak benar, tidak berarti kita boleh memerangi mereka.

Pandangan bahwa kita benar dan merekapun benar, kata Agus Asyari, adalah ambigu, bahkan dualisme. Islam sudah menegaskan lakum dinukum wa liya din (bagimu agamamu, bagiku agamaku). Kita tidak mesti mengakui kebenaran keyakinan mereka, sebab hal itu akan berarti menerima ini, "Hai Muhammad tahun ini kami menyembah Tuhan-mu, tahun depannya lagi kamu menyembah Tuhanku". Islam adalah agama yang pasti benar, tidak bisa dicampuradukkan dengan yang lain. Ibaratnya, kata Asyari, seperti teh yang hendak saya minum, yang sebelumnya sudah saya yakini bahwa itu adalah teh. Jika kemudian orang coba meyakinkan saya bahwa teh itu adalah juga susu, maka tentu itu tidak mungkin saya terima. Jadi, keyakinan itu bukanlah sesuatu yang dinyatakan orang pada umumnya. Berikut pernyataan Agus Asyari selengkapnya:

Pendapat saya, pluralisme dalam Islam berbeda dengan apa yang dikatakan orang. Islam sudah tegas dalam berhubungan dengan non-Islam. Silakan mereka berkeyakinan, dalam keterangan agama dikatakan kita tidak boleh mengolok-olok sesembahan mereka karena mereka akan lebih mengolok-olok lagi. Itu sebenarnya udah cukup bagi kita. Dengan dasar itu bukan mengakui bahwa dia punya sorga sendiri dan kami bersorga sendiri, tapi kami saling menghargai ia beribadatnya secama itu sementara kami semacam ini, bukan artinya saya harus mengakui kebenaran dia, keyakinan tidak bisa doubel, saya meyakini dia benar dan saya mengakui benar, ini kan namanya menyetujui, 
bermakna dualisme atau ambigu, dan itu kalaupun ada menurut saya dari mana dasarnya, hadis atau ayat yang mendukung itu. Kita sudah cukup dengan larangan mengolok-olok sembahan mereka, tapi kita masih tetap mengakui mereka dalam muamalah, kalau sudah mengakui apa ini tidak sama artinya dengan hai Muhammad tahun ini kami menyembah Tuhanmu, tahun depannnya lagi kamu menyembah Tuhan kami, di Alquran tegas dengan lakum dinukum wa liya din. Menurut saya keyakinan Islam adalah sesuatu yang benar bahkan pasti benar tidak bisa kebenaran itu dicampur adukkan, dari sini saya berpegang dan itu yang penting. Misal, ini teh lalu saya disuruh meyakini ini susu, ini tidak bisa, jadi kata yakin harus diberi garis tebal bukan apa yang disebutkan oleh orang pada umumnya.

Pernyataan Agus Asyari di atas menegaskan perlunya menghargai keyakinan yang berbeda. Meski begitu, keyakinan bahwa Islam yang paling benar harus dipegang teguh. Tidak boleh mengikuti pandangan lain yang berlawanan dengan keyakinan itu, sekalipun banyak orang mengatakannya. Penegasan ini menggambarkan keyakinan atas otentisitas Islam dan menolak penyamaan dengan agamaagama lainnya dan apalagi menerima kebenarannya sebagaimana yang diyakini kaum pluralis.

Berkenaan dengan kasus penyerangan di Cirungkrang, menurut Agus Asyari, Muhammadiyah tidak pernah memberikan komando. Muhammadiyah selama ini diakui lebih banyak bergerak pada amar makruf saja, tapi nahi munkar belum ada atau jika ada itu dalam bentuk pendidikan dan sosial, di Muhammadiyah tidak ada banser seperti organisasi lain. $^{51}$

Pandangan yang hampir sama disampaikan oleh Udin, Sekretaris PCM Arjasari, dan Agus Bachtiar, Majelis Dikdasmen PCM Arjasari. Menurut Udin, pluralisme adalah menghargai hak orang lain; tidak boleh memaksakan

\footnotetext{
${ }^{51}$ Agus Asyari (ketua Pimpinan Cabang Muhammadiyah), Wawancara dengan penulis, Buah Batu Regency Bandung, Senin, 16 Desember 2013.
}

keyakinan kepadanya. ${ }^{52}$ Begitu juga dengan Bachtiar. Baginya, pluralisme itu adalah kenyataan dan sesuatu yang niscaya; ada tasamuh (toleransi) bagi rekan non-muslim. Meskipun begitu, baik Udin maupun Bachtiar yakin bahwa hanya Islam agama yang benar, dan kita harus konsisten dengan itu "Inna aldina 'inda Allāh al-Isläm, al-yawma akmaltu lakum dinakum wa atmamtu 'alaykum ni'matī wa raditu lakum al-Islāma dinā. Karenanya, bagi Bachtiar, yang paling penting adalah bagaimana Islam itu dapat dimengerti dan dirasakan (kahartos tur karaos). Sebab, biasanya Kristenisasi itu disebabkan oleh faktor ekonomi. ${ }^{53}$

Ketua PRM Arjasari, Entis Sutisna mengklaim bahwa pendapatnya tentang pluralisme berbeda dengan Gus Dur yang menyatakan bahwa Islam, Kristen, Hindu, dan Budha itu sama. Menurutnya, Islam harus tetap dijaga istikomah sebagaimana diajarkan KH. Dahlan dan HAMKA dengan berpegang pada Alquran dan Sunnah. Berkait dengan perbedaan internal umat Islam-NU, Persis Muhammadiyah dan SI - Sutisna mengusulkan dikembangkannya ukhuwah islämiyyah. Sebab, masing-masing golongan tentu mempunyai kelebihan dan kekurangannya sendiri. Sedang berkait dengan non-Muslim perlu dikembangkan ukhuwah insāniyyah, sebatas penjagaan hubungan dalam bidang sosial saja. $^{54}$

Agak berbeda dengan pandanganpandangan di atas, Atang Saepuloh, Ketua PRM Rancakole, berpendapat bahwa tidak ada toleransi dengan agama lain. Berkenaan dengan hubungan beragama, khususnya dengan non-Muslim, Saepuloh berkomentar, "Biasa saja kalau Bapak di sini mah, palingpaling Bapak melawan yang demikian mah. Ketika Bapak waktu masih pemuda kalau saya mah dulu sableng, hancurkan saja oleh

\footnotetext{
${ }^{52}$ Udin (Sekretaris PCM Arjasari), Wawancara dengan penulis, Bandung, Jum'at, 13 Desember 2013.

${ }^{53}$ Agus Bachtiar (ketua Majelis Dikdasmen PCM Arjasari), Wawancara dengan penulis, Arjasari, Senin, 16 Desember 2013.

${ }^{54}$ Entis Sutisna (Ketua PRM Arjasari), Wawancara dengan penulis, Arjasari, Senin, 16 Desember 2013.
} 
bersama". ${ }^{55}$ Momo Mulawarman, Ketua PRM Pinggirsari, termasuk barisan yang bersuara keras mengenai keberadaan dan kegiatan misionaris Kristen di Arjasari, khususnya di Cirungkang. Momo sendiri terlibat langsung dalam pembangunan mushala (masjid) untuk mengimbangi kegiatan-kegiatan Gereja tersebut.

Perbedaan mereka dalam merespons pluralisme itu, tampaknya dilatari oleh latar pendidikan, tingkat usia, latar pengetahuan, latar sosial dan terutama karakter mereka yang beragam. Pandangan Muslim modernis Arjasari mengenai pluralisme, koeksistensi dan toleransi di atas, selengkapnya dapat gambarkan dalam tabel berikut:

\begin{tabular}{|c|c|c|c|}
\hline No. & Nama & $\begin{array}{l}\text { Pandangan } \\
\text { Mengenai } \\
\text { Pluralisme }\end{array}$ & $\begin{array}{c}\text { Respons atas } \\
\text { Pluralisme }\end{array}$ \\
\hline 1. & $\begin{array}{l}\text { Agus } \\
\text { Asyari }\end{array}$ & $\begin{array}{l}\text { Islam adalah } \\
\text { agama yang } \\
\text { benar dan pasti } \\
\text { benar. Tidak } \\
\text { boleh } \\
\text { mencampur } \\
\text { adukan } \\
\text { keyakinan. }\end{array}$ & $\begin{array}{l}\text { Menghormati } \\
\text { cara ibadah } \\
\text { non-Muslim } \\
\text { dan dilarang } \\
\text { mengolok-olok } \\
\text { sembahan } \\
\text { mereka }\end{array}$ \\
\hline 2. & Udin & $\begin{array}{l}\text { Islam tetap } \\
\text { sebagai agama } \\
\text { yang benar. }\end{array}$ & $\begin{array}{l}\text { Menghormati } \\
\text { keyakinan } \\
\text { orang lain yang } \\
\text { berbeda. }\end{array}$ \\
\hline 3 & $\begin{array}{c}\text { Agus } \\
\text { Bachtiar }\end{array}$ & $\begin{array}{l}\text { Pluralisme } \\
\text { adalah } \\
\text { kenyataan } \\
\text { bahkan } \\
\text { keniscayaan. } \\
\text { Tapi, Islam } \\
\text { adalah agama } \\
\text { yang benar dan } \\
\text { harus } \\
\text { konsisten } \\
\text { dengan Islam. }\end{array}$ & $\begin{array}{l}\text { Ada tasamuh } \\
\text { atau toleransi } \\
\text { kepada non- } \\
\text { Muslim dalam } \\
\text { masalah sosial. }\end{array}$ \\
\hline 4. & $\begin{array}{c}\text { Entis } \\
\text { Sutisna }\end{array}$ & $\begin{array}{lr}\text { Islam, } & \text { Kristen, } \\
\text { Hindu, Budha } \\
\text { adalah tidak } \\
\text { sama. Islam } \\
\text { harus terus } \\
\text { diistiqamahkan } \\
\text {. }\end{array}$ & $\begin{array}{l}\text { Ukhuwah } \\
\text { islāmiyyah } \\
\text { dengan } \\
\text { golongan } \\
\text { seagama, dan } \\
\text { ukhuwah } \\
\text { insāniyyah } \\
\text { dengan non- } \\
\text { Muslim tapi } \\
\text { sebatas bidang }\end{array}$ \\
\hline
\end{tabular}

${ }^{55}$ Atang Saepuloh (Ketua PRM Rancakole), Wawancara dengan penulis, Arjasari, Senin, 16 Desember 2013.

\begin{tabular}{|c|c|l|l|}
\hline & & & sosial saja. \\
\hline 5. & $\begin{array}{c}\text { Atang } \\
\text { Saepuloh }\end{array}$ & $\begin{array}{l}\text { Islam satu- } \\
\text { satunya agama } \\
\text { yang benar }\end{array}$ & $\begin{array}{l}\text { Tidak ada } \\
\text { toleransi } \\
\text { dengan non- } \\
\text { Muslim }\end{array}$ \\
\hline 6. & $\begin{array}{c}\text { Momo } \\
\text { Mulawar } \\
\text { man }\end{array}$ & $\begin{array}{l}\text { Islam satu- } \\
\text { satunya agama } \\
\text { yang benar }\end{array}$ & $\begin{array}{l}\text { Harus } \\
\text { menyaingi } \\
\text { kegiatan- } \\
\text { kegiatan } \\
\text { misionris } \\
\text { Gereja. }\end{array}$ \\
\hline
\end{tabular}

Secara umum, Muhammadiyah Arjasari berpandangan cukup positif tentang pluralisme agama - paling tidak dapat dikategorikan sebagai penganut pluralisme positif, sebagaimana dimaksudkan oleh Kuntowijoyo, yakni lebih mengedepankan penghormatan dan penghargaan terhadap pendapat, pilihan hidup, dan keyakinan keagamaan. Atas dasar itu, Muhammadiyah memandang penting untuk mengembangkan toleransi dan koeksistensi damai antar umat beragama. Islam diyakini Muhammadiyah mengajarkan kita untuk menjalin persaudaraan dan kebaikan dengan belaku adil serta memelihara hak dan kehormatan, baik antar sesama Muslim maupun dengan non-Muslim. Karenanya, kebencian dan sikap tidak ramah terhadap non-Muslim, bagi Muhammadiyah, bukanlah norma agama. Sebaliknya, prinsip penghormatan, saling menolong, kerjasama dan mengadakan hubungan pertemanan, masih tetap menjadi keutamaan moral universal selama yang diajak kerjasama tidak memperlihatkan permusuhan, kekerasan, penindasan, pengusiran dan perang.

Prinsip dasar di atas tampak dalam pandangan sejumlah Muslim modernis (Muhammadiyah) Arjasari. Mereka berkeyakinan bahwa beragama merupakan hak individu. Tidak boleh ada paksaan di dalamnya. Bagi Udin, misalnya, tidak masalah hidup berdampingan dengan non-Muslim; mereka harus tetap dihormati. Dalam setiap kegiatan sosial-kemanusiaan atau sosialkeagamaan, mereka juga ikut dilibatkan. Sekalipun berbeda keyakinan, kalangan Muslim modernis Arjasari dan non-Muslimnya, khususnya di Kampung Cirungkang, memperlihatkan hubungan sosial yang baik, sikap 
toleran, dan koeksistensi damai sebagaimana digambarkan dalam banyak aktivitas sosial di atas.

\section{SIMPULAN}

Berdasarkan paparan di atas, dapat disimpulkan beberapa poin penting sebagai berikut: pertama, masyarakat Arjasari menunjukkan masyarakat yang plural, baik intraumat agama maupun antarumat beragama. Kedua, masyarakat Muslim modernis (Muhammadiyah) Arjasari, Kabupaten Bandung, menunjukan sikap yang positif terhadap pluralisme. Ketiga, meski masyarakat Muslim modernis menunjukan sikap yang positif terhadap pluralisme, mereka tetap memiliki pandangan mengenai otentisitas Islam sebagai agama yang paling benar.

Simpulan ini menepis anggapan bahwa Islam puritan Muhammadiyah sulit menerima perbedaan dan akan menjadi ancaman pluralisme. Dalam kerangka tipologi Kuntowijoyo mengenai respons atas pluralisme, pluralisme kaum Muslim modernis Arjasari dapat dikategorikan sebagai pluralisme positif. Sedang dalam kerangka tipologi Ninian Smart, dapat dikategorikan sebagai tipe eksklusif absolut. Kesimpulan ini lebih jauh menunjukkan bahwa Muhammadiyah memandang tidak perlu adanya revolusi Copernikan a la John Hick dalam teologi. Sebab, bila semua agama dipandang sama dan tidak ada superioritas keagamaan satu dibanding lainnya, maka akan sulit bagi kaum beragama untuk dapat memegang teguh otentisitas keagamaannya. Lagi pula, sikap ekslusif absolut tidaklah sertamerta melahirkan sikap intoleran terhadap keyakinan yang berbeda atau menjadi ektremis-radikal. Sebaliknya, seperti diperlihatkan oleh Muhammadiyah Arjasari, meski secara teologis mereka cenderung eksklusif absolut, namun mereka tetap dapat mengembangkan sikap toleran, saling menghargai dan menghormati, serta sikap koeksistensi damai.

Satu hal penting dari kaum Muslim modernis (Muhammadiyah) Arjasari yang harus dibelajarkan dalam rangka pengembangan teologi pluralisme positif adalah pentingnya pengembangan dialog amal atau dialog kehidupan sebagai paradigma baru keagamaan untuk harmoni bangsa. Dalam dialog ini, setiap anggota komunitas yang berbeda dituntut memiliki komitmen dan kepedulian bersama mengenai isu krusial yang dihadapi dalam kehidupan keseharian. Sebut saja misalnya, isu lingkungan, kebutuhan air bersih, pengelolaan sampah, kesehatan, pendidikan, lapangan kerja, dan sebagainya. Mereka harus bersama-sama, hidup berdampingan dan bekerja sama menyelesaikan problem keseharian tersebut. Problem-based dialogue seperti ini perlu dibelajarkan sebagai paradigma baru untuk membangun harmoni bangsa. Wallahu a'lam.

\section{DAFTAR PUSTAKA}

Abdul Aziz bin Abdullah bin Baz. Majmū", Fatawā Wa Maqālāt Al-Mutanawwi'at. Vol. juz. II, t.t.

Abdullah, M. Amin. Studi Agama, Normativitas Atau Historisitas. Yogyakarta: Pustaka Pelajar, 1996.

Alfian. Muhammadiyah, The Political Behavior of A Muslim Modernist Organization Under Dutch Colonialism. Yogyakarta: Gajah Mada University Press, 1989.

Aloysius Pieris, S.J. Berteologi Dalam Konteks Asia. Yogyakarta: Kanisius, 1996.

Asyari, Suaidi. Nalar Politik NU \& Muhammadiyah, Terj. Mohamad Rapik. Yogyakarta: LKiS, 2010.

Banawiratma, J.B., Zainal Abidin Bagir. Dialog Antarumat Beragama, Gagasan Dan Praktik Di Indonesia. Bandung: Mizan, 2010.

Banchoff, Thomas, ed. Religious Pluralism, Globalization and World Politics. New York: Oxford University Press, 2008.

CRCS. Laporan Tahunan Kehidupan Beragama 2010. Yogyakarta: Sekolah Pascasarjana, Universitas Gadjah Mada, 2010.

- Laporan Tahunan Kehidupan

Beragama 2012. Yogyakarta: Sekolah Pascasarjana, Universitas Gadjah Mada, 2012.

Esack, Farid. Al-Quran, Liberalisme, 
Pluralisme, Membebaskan Yang Tertindas. Translated by Watung A. Budiman "Qur'an, Liberation and Pluralism, An Islamic Perspective of Interreligious Solidarity against Oppression". Bandung: Mizan, 2000.

- Qur'an, Liberation and Pluralism, An

Islamic Perspective of Interreligious Solidarity against Oppression. England: Oxford Oneworld Publications, 1997.

Fealy, Greag. Ijtihad Politik Ulama, Sejarah NU 1952-1967. Yogyakarta: LKiS, 2003.

Gellner, Ernest. Muslim Society. Cambridge: Cambridge University Press, 1981.

Hassan, Riaz. Islam, Dari Konservatisme Sampai Fundamentalisme. Translated by Dewi Haryani S. Jakarta: CV. Rajawali, 1985.

- Keragaman Iman, Studi Komparatif Masyarakat Islam. Translated by Fuad Jabali Jajang Jahroni, Udjang Tholib. PT Rajagrafindo Persada, 2006.

Hick, Joh. God and the Universe of Faiths. Philadelphia: The Westminster Press, 1982.

Hick, John. A Christian Theology of Religions (Louisville: Louisville: Westminster/John Knox, 1995.

- An Interpretation of Religion (London. Macmillan; New Haven: Yale University Press, 1989.

- God and the Universe of Faiths. Philadelphia: The Westminster Press, 1982. . God Has Many Names, Essays in The Philosophy of Religion. (England: Oneworld Oxford, 1973.

- Problem of Religious Pluralism. London: Macmillan; NY: St Martin's, 1985.

- The Metaphor of God Incarnate. Louisville: Westminster/John Knox, 1994.

Hines, Declan Marmion and Mary E., ed. The Cambidge Companion to Karl Rahner. New York: Cambridge University Press, 2005.

Husaini, Adian. Pluralisme Musuh AgamaAgama, Pandangan Katolik, Protyestan, Hindu Dan Islam Terhadap Pluralisme Agama. Dewan Dakwah Islamiyah Indonesia, 2010.
Husein, Fatimah. Muslim-Christian Relations in The New Order Indonesia, The Exclusivist and Inclusivist Muslims Perspective. Bandung: Mizan, 2005.

Indonesia, Majelis Ulama. Himpunan Fatwa Majelis Ulama Indonesia, 92-97. Jakarta: Erlangga, 2005.

Jainuri, Achmad. Ideologi Kaum Reformis: Melacak Pandangan Keagamaan Muhammadiyah Periode Awal. Surabaya: Lembaga Pengkajian Agama dan Masyarakat, 2002.

Johnston, William M., ed. Recent Reference Books in Religion: A Guide for Students, Scholars, Researchers, Buyers, \& Readers. Chicago: Fitzroy Dearborn, 1998.

KONTRAS. Laporan Hak Asasi Manusia Peristiwa Penyerangan Jama'ah Ahmadiyah Cikeusik 6 Februari 2011. Jakarta: Komisi untuk Orang Hilang dan Tindak Kekerasan, 2011.

Kuntowijoyo. Muslim Tanpa Masjid, EsaiEsai Agama, Budaya Dan Politik Dalam Bingkai Strukturalisme Transendental. Bandung: Mizan, 2001.

Kurzman, Charles. Wacana Islam Liberal, Pemikiran Islam Kontemporer Tentang IsuIsu Global. Edited by Bahrul Ulmu. Jakarta: Paramadina, 2003.

"Laporan Kepengurusan PCM Arjasari Masa Jabatan 2006-2011," n.d.

Muhammadiyah, Majelis Tarjih dan Pengembangan Pemikiran Islam PP. Tafsir Tematik Al-Quran Tentang Hubungan Sosial Antarumat Beragama. Yogyakarta: Suara Muhammadiyah, 2000.

Noer, Deliar. Gerakan Modern Islam Di Indonesia 1900-1942. Jakarta: LP3ES, 1980.

Osman, Mohammed Fathi. Islam, Pluralisme Dan Toleransi Keagamaan: Pandangan AlQuran, Kemanusiaan, Sejarah Dan Peradaban. Translated by Irfan Abubakar. Edisi digi. Jakarta: Democracy Project Yayasan Abad Demokrasi, n.d.

Peacock, James L. Purifying the Faith: The Muhammadiyah Movement in Indonesian Islam. California: The Benyamin/Cumming Publishing Company, 1978. 
Rahardjo, M. Dawam. "Dari Puritanisme Ke Fundamentalisme: Muhammadiyah Berbalik Arah." In Esai-Esai Pemikiran Moh. Shofan Dan Refleksi Kritis Kaum Pluralis, Ali Usman. Jakarta: LSAF dan Ar-Ruzz Media, 2008.

Rahman, Fazlur. Islam Dan Modernitas Tentang Transformasi Intelektual. Bandung: Pustaka, 1985.

. Major Theme of the Quran. Chicago: Bibliotheca Islamica, 1980.

—. Tema Pokok Quran. Translated by Anas Mahyudin "Major Theme of the Quran". Bandung: Pustaka, 1996.

Rahner, Karen Kilby Karl. Theology and Philosophy. London and New York: Routledge: Routledge, 2004.

Ridwan, Nur Khalik. Agama Borjuis, Kritis Atas Nalar Islam Murni. Yogyakarta: ArRuzz, 2004.

Schuon, Frithjof. The Transcendent Unity of Religions. India: Quest Books, 2005.

Shihab, Alwi. Membendung Arus, Respons Gerakan Muhammadiyah Terhadap Penetrasi Misi Kristen Di Indonesia. Bandung: Mizan, 1998.

Thoha, Anis Malik. Tren Pluralisme Agama, Tinjauan Kritis. Jakarta: Perspektif, 2005.

Tyler, Aaron. Islam, The West, and Tolerance, Conceiving Coexistence. New York: Palgrave Macmillan, 2008.

Walzer, Michael. On Toleration, Castle Lectures in Ethics, Politics, and Economics. New Haven and London: Yale University Press, 1997.

Watt, W. Montgomery. Islamic Fundamentalism and Modernity. London: Routledge, 1988.

\section{Internet}

"Agama Damai". Diakses pada 29 Nopember $2013 . \quad$ http://www.answeringislam.org/indonesian/islam-danterorisme/agama-damai.html.

Suara Merdeka, 3 Agustus 2005. Diakses pada Kamis, $\quad 12 \quad$ September 2013. http://www.suara merdeka. om/harian/0508/03/nas08.htm.
"Perbandingan Agama Islam dan Kristen". Diakses $\quad 10 \quad$ September 2013. http://www.isadanislam.com/perbandingankristen-dan-islam/ agama-islam-ataukristen-mana-menekankan-damai.

The Jakarta Post online edisi 26 November 2008. Diakses 20 Nopember 2013 http://www.thejakartapost.com/news/2008/ 12/09/nu-muhammadiyah-have-failedpromote-pluralism-grassroots.html

Infoanda. Diakses pada Sabtu, 16 Nopember 2013.http://www.infoanda.com/followlink. php?lh=DFEBCQNSVAJc.

\section{Wawancara}

Asyari, Agus (ketua PCM Arjasari). Wawancara oleh penulis. Buah Batu Regency Bandung. Senin, 16 Desember 2013.

Bachtiar, Agus (ketua Majelis Dikdasmen PCM Arjasari). Wawancara dengan penulis. Arjasari. Senin, 16 Desember 2013.

Atang Saepuloh (Ketua PRM Rancakole). Wawancara oleh penulis. Arjasari. Senin, 16 Desember 2013.

Dadang. Wawancara oleh penulis. Arjasari. 28 Oktober dan 5 Nopember 2013.

Mulawarman, Momo (ketua PRM Pinggirsari). Wawancara oleh penulis. Arjasari. 5 Nopember 2013 dan 16 Desember 2013.

Sobar, Dede. Wawancara oleh penulis. Arjasari. 5 Nopember 2013.

Somantri, Wawan. Wawancara oleh penulis. Arjasari. 5 Nopember 2013.

Suherman, Asep. Wawancara oleh penulis. Arjasari. 13 Nopember 2013.

Sutisna, Entis (Ketua PRM Arjasari). Wawancara oleh penulis. Bandung. 16 Desember 2013.

Udin (Sekretaris PCM Arjasari). Wawancara oleh penulis. Bandung. 13 Desember 2013. 